\title{
原発性脊椎・脊髄腫揚の治療の検討
}

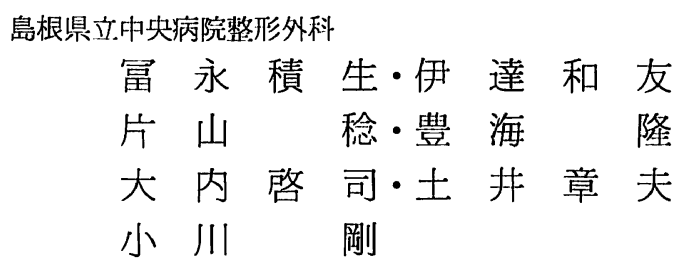

\section{Treatment of Primary Spinal Column and Cord Tumor}

by

Sekio Tominage, Kazutomo Date, Keiji Ouchi, Minoru Katayama, Takashi Toyoumi, Akio Doi \& Tsuyoshi Ogawa

Dept. Or thopedic Surgery, Shimane Prefectural Central Hospital

Primary spinal column and cord tumors, treated in the past 10 years, were listed. There were 23 cases of the former and 23 of the letter. Of these tumors, recurrent or malignant ones were picked up. Especially interesting 5 cases were presented in detail and discussed.

Case 1, a 67 years old male; sphenooccipital chordoma, originating from the lower clivus and projecting into the foramen magnum.

Case 2, a 79 years old male; sacrococcygeal chordoma, originating from the lower sacrum and projecting into the pelvic cavity.

Case 3 , a 45 years old male; thoracic giant cell tumor, originating from the $7 \& 8$ th vertebrae and invading into the left thoracic cavity and the spinal canal.

Case 4 , a 48 years old female, cauda equina neurinoma, which arose multiply like a cluster of grapes.

Case 5 , a 62 years old male; multiple myeloma, which transformed from solitary cervical myeloma.

Case 5 is dead and the others are alive.

Case 1, 2, 3 and 5 relasped after excision and radiation. These tumors including that of case 4 became progressively larger in size and more invasive into the adjacent tissue.

The method of treatment was searched, however, it was not found.

\section{はじめに}

過去10年間に脊髄麻症を伴ない何らかの組織診断に より確定した原発性の脊椎・瓷髄腫瘍について神経学 的, レ線学的所見および治療, 予後を分析しとくに再 発性のもの, 覀性のものについて検討した。

とくに治療に難渋した症例を呈示し, 苦斗の中から 解決法がないかを模索したものである.

\section{〔対象症例の分析〕}

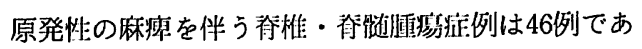

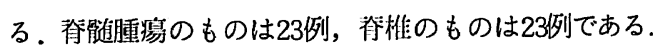
これらの腫湯の確定組織診断は手術時の open biopsy, 多発性:骨髄腫, 价血病などの胸骨穿刺による needle biopsyを含むもの14例, 手術による摘出嫩本によ るもの32例である.

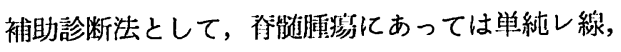
断層像, ミエロ, ミエロ CT, 郬椎腄准にあってはCT, 


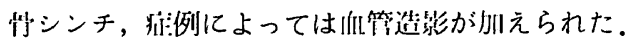

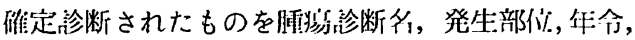
性: 治療法, 現在の follow-up の状態を表 1,2 に小す。

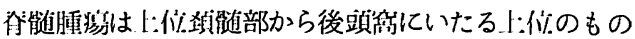
meningioma, 佒块部の䏚特咶胢 neurofibroma, meningioma のもの条 1 例づつ, 全㸚优進部のもの ependymoma

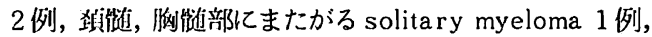
胸铕部のもの malignant lymphoma 1 例, hemangioma 2 例, neurinoma 4 例, 䜿鹿神経部ではneurinoma 8 例, meningioma 2例，うち 1 例は琹悱である.

これらのうち死亡は ependymoma の 2 例, malignant 1 例, malignant meningioma 1 例であった. 再発をく り返し治䝤中のものは chordoma の2例, neurinoma の1例である.その他の neurinoma, hemangioma, meningioma は摘出術後再発なく治痛した。
次に，初宱腫煬のものは斜台に発生し後頭䆚にいた る choroma 1 例, 頝椎部は os teochondroma の 2 例, 胸椎部は angiosarcoma, giant cell tumor, eosinophilic granuloma 各 1 例, 腰椎部leukemia 1 例, 尾仙椎部 chordoma 3 例, 多椎部 multiple myeloma 13例である.

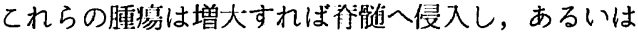

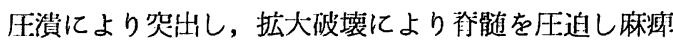
を来すものである．治㺘といえるものは osteochondroma の 1 例, eosinophilic granuloma の 1 例のみで, 死亡は leukemia chordoma の2例, myeloma の13例 である．その他は経過観祭中の osteochondromaの 1 例, 治療継続中のものは angiosarcoma, giant cell tumor, myeloma の冬 1 例である. myeloma 以外は現 在入院中であり治療に苫斗している。

表 1 SPINAL CORD TUMOR

\begin{tabular}{|c|c|c|c|c|c|}
\hline location & tumor & $\begin{array}{l}\text { sex } \\
\text { age }\end{array}$ & site & trestment & $\begin{array}{l}\text { status at } \\
\text { follow-up }\end{array}$ \\
\hline $\begin{array}{l}\text { cervical } \\
\text { upper } \\
\text { middle } \\
\text { entire } \\
\text { cervico- } \\
\text { thoracic } \\
\end{array}$ & $\begin{array}{l}\text { meningioma } \\
\text { neurof ibroma } \\
\text {-dumbbell } \\
\text { meningioma } \\
\text { ependymoma } \\
\text { ependymoma } \\
\text { solitary sol } \\
\text { myeloma } \\
\end{array}$ & $\begin{array}{c}\text { f. } 65 \\
\text { f. } 40 \\
\text { f. } 60 \\
\text { f. } 35 \\
\text { m. } 17 \\
\text { m. } 48\end{array}$ & $\begin{array}{l}\text { id } \\
\text { id } \\
\text { ed } \\
\text { id } \\
\text { me } \\
\text { me } \\
\text { ed }\end{array}$ & $\begin{array}{l}\text { exc, } \\
b x, d c \\
\text { exc } \\
b x, d c \\
b x, d c \\
\text { exc }\end{array}$ & $\begin{array}{l}\text { relasped } \\
\text { treating } \\
\text { treating } \\
\text { cured } \\
\text { dead } 1 \mathrm{yr} \\
\text { dead } 4 \mathrm{yr} \\
\text { improved }\end{array}$ \\
\hline $\begin{array}{l}\text { cauda-eq- } \\
\text { uina }\end{array}$ & $\begin{array}{l}\text { lymphosarcoma } \\
\text { neurinoma } \\
\text { meningioma } \\
\text { " } \\
\text { " } \\
\text { hemangioma } \\
\text { " } \\
\text { neurinoma } \\
\text { " } \\
\text { " } \\
\text { " } \\
\text { " } \\
\text { " } \\
\text { " } \\
\text { meningioma } \\
\text {-malignant } \\
\text { neurinoma }\end{array}$ & $\begin{array}{c}\text { m. } 68 \\
\text { m. } 45 \\
\text { f. } 55 \\
\text { f. } 35 \\
\text { f. } 45 \\
\text { f. } 52 \\
\text { m. } 43 \\
\text { f. } 20 \\
\text { m. } 42 \\
\text { m. } 36 \\
\text { f. } 30 \\
\text { m. } 41 \\
\text { f. } 40 \\
\text { f. } 48 \\
\text { f. } 30 \\
\text { m. } 61 \\
\text { f. } 37\end{array}$ & $\begin{array}{l}\text { ed } \\
\text { id } \\
\text { " } \\
\text { " } \\
\text { " } \\
\text { " } \\
\text { " } \\
\text { id } \\
\text { " } \\
\text { " } \\
\text { " } \\
\text { " } \\
\text { " } \\
\text { " }\end{array}$ & $\begin{array}{l}\text { bx, ra } \\
\text { exc } \\
\text { " } \\
\text { " } \\
\text { " } \\
\text { " } \\
\text { " } \\
\text { " } \\
\text { " } \\
\text { " } 5 \\
\text { " }\end{array}$ & $\begin{array}{c}\text { dead } 1 \mathrm{yr} \\
\text { cured } \\
\text { " } \\
\text { " } \\
\text { " } \\
\text { " } \\
\text { " } \\
\text { " } \\
\text { " } \\
\text { " } \\
\text { " } \\
\text { " } \\
\text { treating } \\
\text { cured } \\
\text { dead } 1 \mathrm{yr} \\
\text { cured }\end{array}$ \\
\hline
\end{tabular}

$*$ exc $=$ total or subtotae excision $\mathrm{ra}=$ radiotherapy

ed=extradural, $m e=$ medullar, id $=$ intradural $\mathrm{bx}=$ biopsy 
表 2 SPINAL COLUMN TUMOR

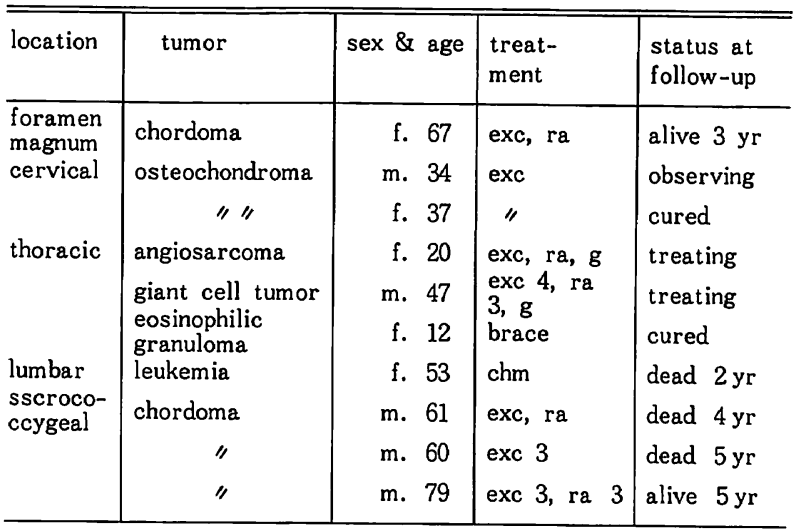

multiple myeloma 13 patients, $36-75$ yrs old survival duration 1-8 yr, chm, str

$* \mathrm{chm}=$ chemotherapy, $\mathrm{str}=$ steroid, $\mathrm{g}=\mathrm{graft}$

\section{〔症例の紹介〕}

治療に苦斗中の, あるいは苦斗した症例, 斜台部か ら発生した chordoma, 尾仙椎部の chordoma, 胸椎 部の giant cell tumer, 馬尾神経の neurinoma, solitary で頚椎部に発生し，その後間もなく multiple とな った myeloma 例を紹介する。

てれらの, 症例について, 治療はいかにすべきか, 治療の可能性はあるか, とくに手術法は，さらに，診 断法について，とくにCT，CTMの有用性についてふ れる。

*後頭窩 chordoma，67才，女性。

1982年 3 月, 後頭・頝部痛が生じ, 右上, 下肢の脱 力を来たし歩行が困難となった。

同年 7 月に入院，右側運動性の完全なる Brown-Sequard型麻盘であった. 右舌下神経が障害され，右に Horner's sign があった。(図 1)

単純レ線, 断層像では頝椎, 頭蓋底部に異常を認め ず．椎骨動脈造影ではその奇形をみるも異常なし，骨 シンチも異常なしリコールの通過は良好, 細胞数, 蛋白量の増加を見ず．頝部でのミエロは充盈する． $\mathrm{CTM}^{111}$ で胸幹部下方からC、にいたる左側への偏位がみ られ，右側部前側方に不規則に造影剤が入り込んだ腫 瘍像をみる。

同年 9 月に subtotal craniotomy, C 1 \& C 2 laminectomy を行ない，斜台下部から発生し右側延鹃，舌
下神経根，頝艏を突き上げ，乙れを左方に偏位させて いた. $2 \mathrm{~cm}$ 大 球状，灰青出の腫跒をほぼ全摘した。

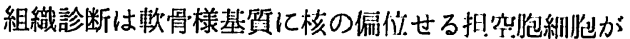
みられ chondroid chordoma であった。

術後は劇的に麻䁬の改善がみられ独步が可能となっ たが，約 1 年後に再発し，左上・下肢麻娚!となった。 CTでは右側頭蓋底部を占拠する巨大な婳䊑となって いた。

福岡大学脳神経外科で除圧手術, radiation し,一㭙 症状の改善をみたという，その後, 不明.

文献上, chordoma の発生频没" 1100 万人に0.51 と 稀れであり，部位は尾仙椎部35\%に次いで斜台部15\%， その他会椎となる．生命上重大な部位であり，手術的 に完全摘出は困難である．前方より斜台を令めて摘出 する手術 ${ }^{51}$ は危険すぎる。私共は foramen magnum部 に発生した meningioma も考えていた。このもののは 1 例あり，2 回の手術も亜摘出に終った。リ八中であ ろ.

この腫煌は大量の放射線照射にも効果は薄い。”遠 隔転移は10４3\%，経過年数につれ，肺，リンパ腺， 他の所へと転移する。再発は必発であり，手術後はよ り大きな腫溜となる3! 増大は緩慢であり進衍性に破壊 する。生存期間は平均 5 年である。

腫場の部位と性状により，今後とるべき治療法は見 当らないようだ。

*尾仙椎部 chordoma, 79才，男吽: 


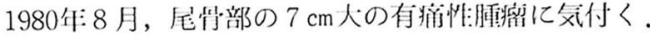
间年: 9 月に入院。単純レ線像で仙椎下方 $1 / 3$ のlyticな病

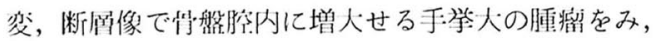

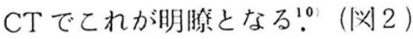

9 月16日, 第 1 问の後方より摘出術在行う。仙椎畐

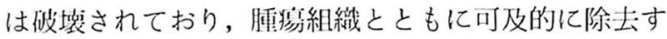
る。

組織学的に線維恻:索状の风別内に核の偏在した担空 胞絒胞をみる chordoma であった。

その後も徐々に増大していく.82年12月に 2 回目， 83年: 2 月に 3 叫目の摘出術, 術後に $6,000 \mathrm{rad}$ 照射し
た。83年12月にさらに増大し $9,000 \mathrm{rad}$ を加えた。し かし骨船腔へ增大し続け，84年 9 月，4回目の摘出術 を行った。

現在，仙椎上方まで破壊し骨盤腔に侵入する.CTで 明膫であり，総腸㔠動脈造影でとくに殿部動脈から栄

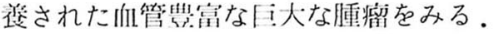

現在，殿部腫溜は自潰し出血性である，膀胱面腸障 害はない，遠隔転移はない，一般状態は高令にもか〉 わらず良好である.

前方から骨般腔内で栄意血管を結紮し，後方より腫 蹓を摘出し，回旋植皮をしょうと計画中である。これ

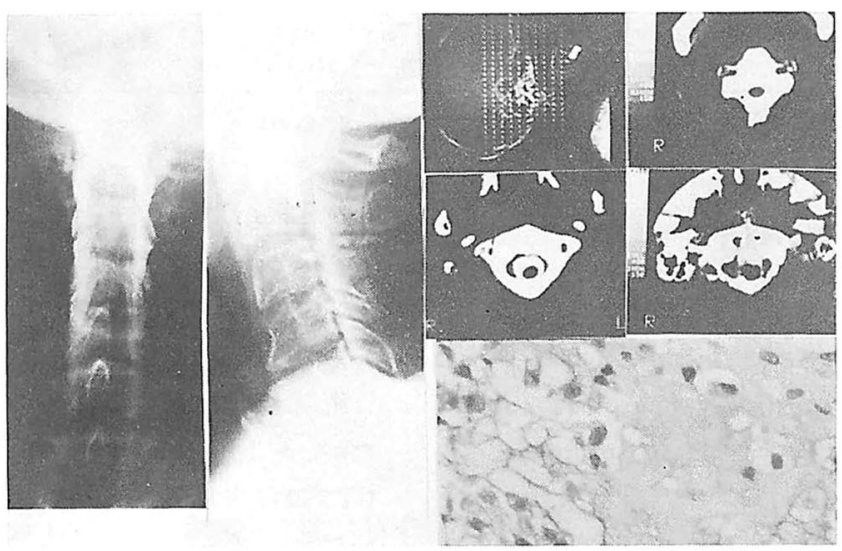

図167才，女性，後頭骷斜台下部より発生した Chordoma 例. 単純レ線, 断酋像, ミエロ, 椎骨動脈造影, 骨ジンチでひっかか

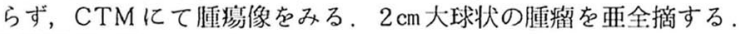
術後独歩可能となるも 1 年後により大きな隀咳形成となる.

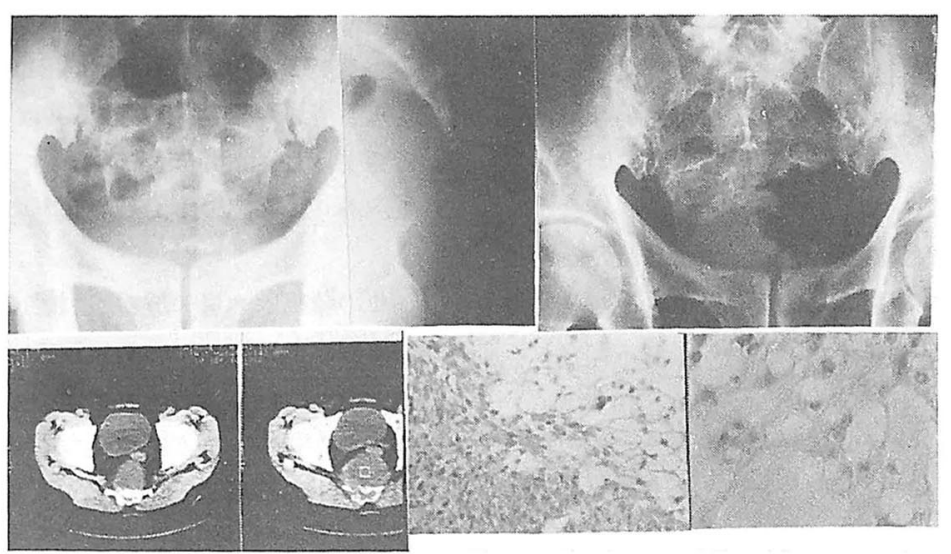

図279才，男性：尾仙椎部 chordoma 例。骨盤腔に浸潤する。乙れ を可及的に摘出するも右上闵のでとく仙椎全体へと破壊が進む. 
にて腫婸を摘出し，仙椎部を再建しえても ${ }^{6 !}$ 残れる腫 瘍細胞は増殖していてう。.

過去 3 例の尾仙椎部 chordoma 㠻経験した。すべて 巨大なる腫瘤を形成した。手術と照射をくり返し，4， 5 年で死亡していった。

*胸椎部 giant cell tumor, 45才. 男性.

1964年 3 月，会社の定期胸部レ線像にて心缄後方の 巨大なる腫瘤を指摘された。その年の 9 月，67年10月 と結核療扂所で開胸手術を受けたが摘出は不能であっ た。

次第に雨下肢が麻痺し放射線療法のため，69年11月 に当院に入院した. 6,000 rad照射後, 麻瘦は完全と なった．上行性ミエロはT。部で完全に停止した。レ線 像は $\mathrm{T}_{7 \sim 9}$ 左側半分を lytic, ballooned-outに破壊し， 心臟後方に巨大なる陰影をみた。(威 3 a 。 b )

70年 3 月，椎弓切除術にて椎管内に侵入せる腫痬組 織を除去し，椎体および胸腔内の被膜に覆われた黄色， 脆弱引な組織約 $200 \mathrm{~g}$ を搔爬，摘出した。出血が強く大呈 にスポンゼルをつめた。

組織診断は線維性腫婸細胞が増殖し，多核巨細胞が

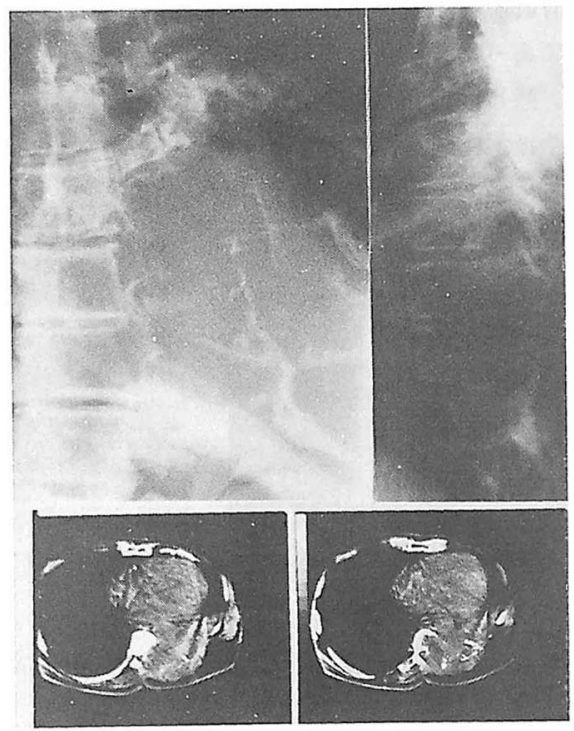

図3 a 45才, 男珄. 胸椎 giant cell tumor 過去開胸手術, 椎弓切 除術で下肢麻瘏はとれ15年間 何ら症状なく経過する。再発 せる巨大な腫瘍，心淢後方に 浸潤する。

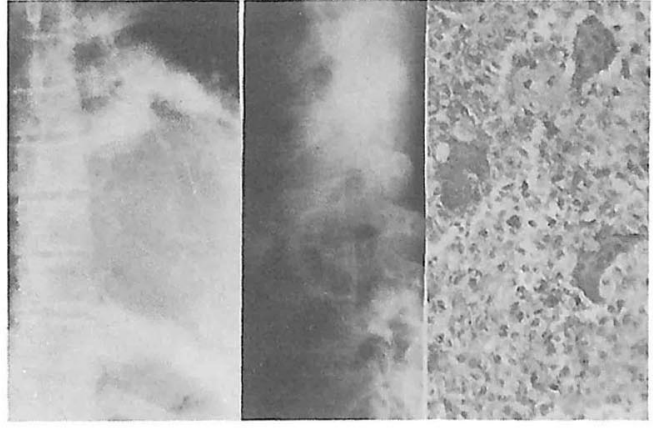

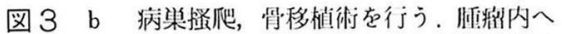
はオキッセルをつめた。組緎兴的所見 は巨緗胞婳であった。

散在する，核分裂は少ない. giant cell tumor，Jafe の【度であった。

術後，麻瘦は消失し，84年 6 月まで14年間何ら症: はなかった。しかし，雨下肢の片全潹独が再発した。 定期的に撮るレ線像で椎体破壊か進行した。

84年11月, 後方より可及的に摘出した。術後に4,000 $\mathrm{rad}$ 照射した。本年 2 月，5回目の摘出術と椎体への

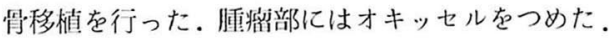

術後に穈瘦は改善した。しかし, 今後も再発增大し よう.

giant cell tumorは radioresistantであり，50\% と 再発性にとみ，radiation後に悪化しやすい. 腎吽化は 10\%といわれるも， slow-progressive で破壤性:であ

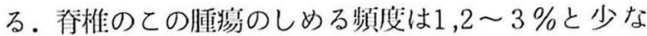

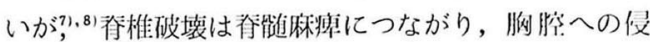
潤は肺蔵を压迫する。自謴すれば重篤となる。(威 4 )

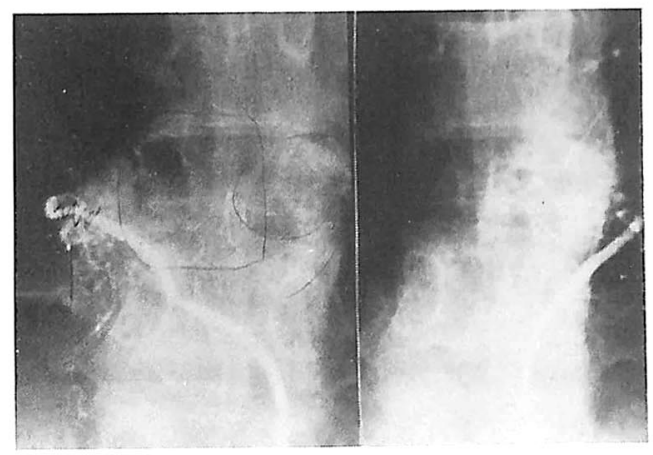

図420才, 六性: 。胸椎 angiosarcoma例.

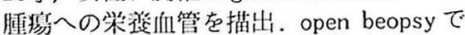
上記も耪断, radiation後, 骨移值術を行 う. 
手術が唯一の手段であるが, 完全摘出は困難であり， 20才，女性の胸椎血管肉腫での血管造影でみたでとく 栄坫血管の embolization ${ }^{91}$ は今後試みられる方法であ ろう。

*馬尾部多発性 neurinoma，48才。女性.

1976年10月に腰痛と両下肢痛に気付き夜間痛が激烈 となった。下肢の脱力と尿失禁が増強した。同年12月， 他医にて腰椎々弓切除術を受けた。 neurinomaだった。 その後も疼痛が持続し下肢麻痖が進行するため77年 4 月に来院した。

レ線像で $\mathrm{L}_{2-5}$ 椎体に多発性の空洞化侵潤像 posterior scallosing みる.之エロは完全にブロックする. CTは椎体皮質を薄く残すのみである.

同年 6 月，80年 3 月，81年11月，84年 3 月と，その 後の再発に対し摘出術を行った. 馬尾神経の枝にブド ウ房状に腫陽組織が無数に付着していた. 出血の中で これを剝離していった。

組織晾断は線維性の絒胞核が棚状配列した neurinoma, Antoni A型であった。(図 5)

現在，下肢麻瘏のため足部に装具をつけ $\mathrm{T}$ 字杖にて 歩行する。再び疼痛が増強してきた。 さらに手術によ り expansive となった椎管腔の解放が必要である.

neurinoma の多発性例は文献上 ${ }^{21,13)}$ 多数の報告をみ る。全摘出は必ずしもなされていない. 本症例は椎体 の破壤が高度であり instrument による再建術も必要 である。
米単発性から移行した multiple myeloma 62才, 男性。 79 年 3 月, 澒部痛, 雨上肢痛, 四肢の脱力に気付き, 同年 4 月，来院する.

レ線像で $\mathrm{C}_{5}$ 椎体の expansive, lytic の破壊像をみる. ミエロはとの部で完全ブロックを呈し, 椎骨動脈造影 でこの部の血管増生をみる。骨シンチもとの部のみ堛 積する。

原発性悪性腫瘍として，ルーチンに胸骨穿刺を行う に myeloma cell が増殖, 血清免疫泳動で IgGの増加を みる。

solitary myeloma と考えるも, radiation 後のレ線 像は頭蓋, 简椎と多発性の punched-out 像を示し multiple myeloma と謬断が明確となった。

化学療法, ステロイド療法を行うも全身状態が悪化 し 1 年後に死亡した。

本症例の骨シンチでとらえた myelomaは䅡椎部のみ であったが，てれが radiation後に一致して急に全身 に多発性となった。しかし, 入院時の骨髄穿刺で myeloma cell をみたことは, すでに全身性のものであっ たわけである.（図6)

13例の myeloma 例はすべて尙椎への増殖, 破壊に

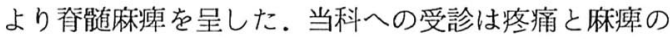
ためであった，私共はての治療を行ない内科医か浙薬 した，激しい疼痛への除痛に radiation を行った。 年令は36才゙から75才で 1 ～年の期間で死亡した. 稀れに頝髄・胸髅部の硬膜外腫汮でみたごとく骨を

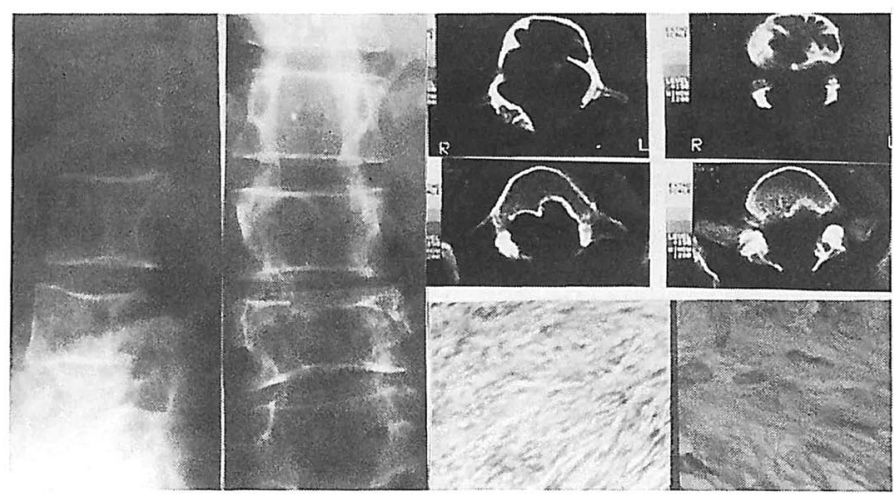

図548才，女性，再発をくり这す馬尾神経部多発性神経鞘腫例。 過去 5 回をモブドウ房状の無数の腫爈を摘出した。 1 年おきくら いに椎営が expansive となり夜間痛が強くなり来院する。CTは 椎体过縁皮質を残すのみ, 瘦ており instrumentationは無理. 


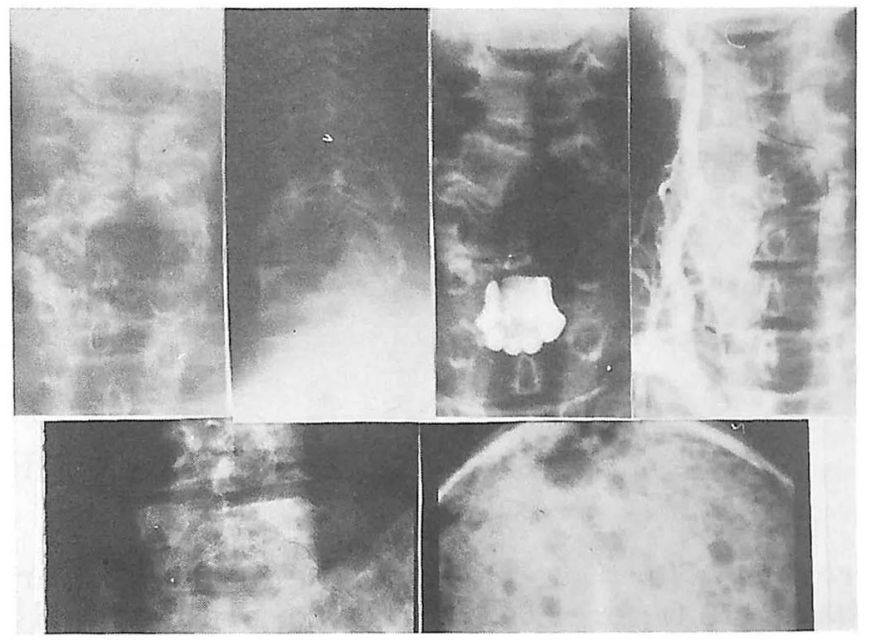

図6 62才, 男性. solitaryから multiple myeloma と移行した症例. 頝椎部の病変のみで四肢麻㿉のため来院，ての部 radiation後の2 ヶ月目に頭蓋・金椎と多発性の病変をみる。

侵さないsolitary myeloma ${ }^{14)}$ がある.非常に緩従な経 過をみて全身性に移行するといわれる。乙の症例はす でに8年となるがmultipleとはならない。

\section{文献}

chordomaに関して

1) Eriksson, B. et al: Chordoma, a clinicopathologic and prognostic study of a Swedish national series, Acta Orthop. Scand., 52:49-58, 1981.

2) Harwick, K. D. et al: Craniocervical chordoma, Am. J. Surg., 138, 512-516, 1979.

3) Mindell, E. R. : Chordoma, J. B. J. S., 63 A : 501-505, 1981.

4) Pearlman, A. W. et al: Radical radiation therapy of Chordoma, Am. J. Roentgenol., 108: 333341, 1970.

5) Quthkelch, A. N. : Anterior approach to recurrent chordoma of the clivus, J. Neurosurg. , $36: 670$ -673, 1972.

6）赤居正義, 他：仙椎腫瘍, その治療を機能面からみ た予後, 整形 災害外科, $24: 1801-1811,1981$. giant cell tumor関して

7 ) Cohen, D. M. et al: Vertebral giant cell tumor and variants, Cancer, $17: 461-469,1964$.

8) Dahlin, D. C. : giant cell tumor of vertebrae above the sacrum, a review of 31 cases, Cancer, $39: 1350-1356,1977$.

9) Djidjian, R. et al : Superselective arteriographic embolization by the femoral route in study of 50 cases, Neuroradiology, $6: 132-142,1973$.

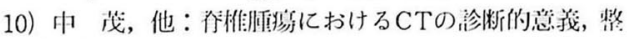
形外科, $32: 491-499,1981$.

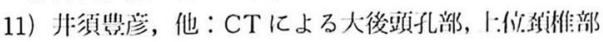
疾患の骖断, 脳神経外科, $9: 1251-1255,1981$. multiple neurinomaに関して

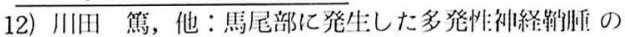
1 例, 䧗本整形外科, $17: 65-68,1982$.

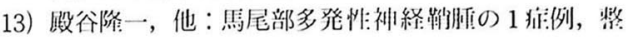
形外科, 35 : 1717-1719, 1984. myelomaに测して

14) Epstein, B. S. : The vertebral column, an atlas of tumor radiology, Year Book Medical Publishers, 1974. 